\title{
mCD24, a Glycoprotein Transiently Expressed by Neurons, Is an Inhibitor of Neurite Outgrowth
}

\author{
Derryck Shewan, ${ }^{1}$ Viviane Calaora, ${ }^{2}$ Peter Nielsen, ${ }^{3}$ James Cohen, ${ }^{1}$ Geneviève Rougon, ${ }^{2}$ and Hervé Moreau ${ }^{2}$ \\ 'Department of Developmental Neurobiology, United Medical and Dental Schools, Guy's Campus, London SE1 9RT, \\ United Kingdom, 'Laboratoire de Génétique et Physiologie du Développement, CNRS UMR 9943, Faculté des Sciences \\ de Luminy, 13288 Marseille Cedex 9, France, and ${ }^{3}$ Max Planck Institut für Immunbiologie, D7800 Freiburg, Germany
}

In the immune system, mCD24, the mouse homolog of the human glycosyl phosphatidylinositol-anchored glycoprotein CD24, may play a role in cell adhesion. In the nervous system, the function of mCD24 has not been determined, but its transient expression by neurons suggests that it may be involved in axon growth in development. Here we show that retinal ganglion cells (RGCs) and dorsal root ganglion (DRG) neurons express mCD24 in the developing but not adult mouse in vivo and in DRG neurons of the injured adult peripheral nervous system (PNS). In vitro, mCD24 was expressed by immature neurons and by a subpopulation of adult DRG neurons. To analyze the possible function of mCD24 in the nervous system, we prepared rat $\mathrm{C} 6$ glioma cells stably transfected or retrovirally infected with mCD24 cDNA. The cells did not exhibit changes in their adhesive properties or cell division rate after

$\operatorname{mCD} 24$, the mouse homolog of human $\mathrm{CD} 24$, initially defined by use of monoclonal antibodies (mAbs) as heat-stable antigen (Springer et al., 1978; Symington and Hakomori, 1984) and also known as p31 (Nédelec et al., 1992) or nectadrin (Kadmon et al., 1992), has attracted much interest because of its transient expression in development on cells of the hematopoietic lineage (Hardy et al., 1991), neurons (Rougon et al., 1991; Nédelec et al., 1992), and some epithelial cells (Shirasawa et al., 1993). mCD24 is a glycoprotein with a peptide core of only 30 amino acids (Kay et al., 1991; Wenger et al., 1991), anchored to the membrane via a glycosyl phosphatidylinositol (GPI) group (Pierres et al., 1987). Its molecular weight varies between different cell types. In Western blots of lymphoid cells, mCD24 appears as a broad band of 40-68 $\mathrm{kDa}$ (Alterman et al., 1990), whereas in embryonic brain it ranges between 28 and $35 \mathrm{kDa}$ (Rougon et al., 1991). Its amino acid sequence, together with biochemical analyses, suggest that it is highly glycosylated and heterogeneous with respect to both its $\mathrm{N}$-linked and O-linked carbohydrates (Alterman et al., 1990; Kay et al., 1991; Nédelec et al., 1992).

\footnotetext{
Received Nov. 27, 1995; accepted Jan. 4, 1996.

This work was supported by Grant CT930326 from the EEC (Concerted Action in Biotechnology) (G.R., J.C.), grants from the Medical Research Council (J.C.), Association Française contre les Myopathies (G.R.), Ligue Départemental des Bouches du Rhone de Lutte contre le Cancer (H.M.), and a European Molecular Biology Organization short-term fellowship (D.S.). We thank Dr. J. Major (Washington University School of Medicine, St. Louis, MO) for providing us with the retroviral vectors, and Kevin Fitzpatrick and Sarah Smith for photographic assistance.

Correspondence should be addressed to Derryck Shewan, Department of Developmental Neurobiology, United Medical and Dental Schools, Guy's Campus, London SE1 9RT, UK.
}

Copyright $\mathcal{O} 1996$ Society for Neuroscience $0270-6474 / 96 / 162624-11 \$ 05.00 / 0$ transfection or infection. When mCD24-expressing cells were used as monolayer substrates for culturing RGCs and DRG neurons, neurite outgrowth was inhibited, depending on neuronal age and on the relative levels of mCD24 in the monolayer. This inhibition, however, was not dependent on the expression of mCD24 by the neurons themselves, because DRG neurons of a mouse deleted of the mCD24 gene showed the same response. These results show that mCD24 interacts in a heterophilic manner with a developmentally regulated molecule expressed by neurons, and they suggest that in vivo, mCD24 may inhibit the further extension or collateral branching of axons in late embryonic development.

Key words: cell surface; CD24; axon-growth inhibition; neurons; in vitro; mouse; rat

In the immune system, CD24 may be involved in cell adhesion (Kadmon et al., 1992). Although it lacks a transmembrane domain, it may be able to transduce signals, because Stefanova et al. (1991) reported in B cells a protein kinase activity coprccipitated with CD24; incubation of $B$ cells with mAbs to CD24 results in the tyrosine phosphorylation of several cytoplasmic proteins. Thus, much evidence exists for possible mechanisms of action of CD24 in the immune system, but its role in the nervous system remains largely unexplored.

In mouse brain, mCD24 is expressed between embryonic day 12 and postnatal day 5 (Nédelec et al., 1992); this concurs with immunolabeling data on developing rat cerebellum (Kuchler et al., 1989) and mouse brain (Caladra et al., in press) showing that $\mathrm{mCD} 24$ is expressed transiently on postmitotic migrating neuroblasts and in developing axonal tracts. This strategic timing of expression prompted us to study the potential influence of mCD24 on axon outgrowth. We prepared a stable cell line and isolated individual clones of C6 rat glioma cells expressing different levels of mCD24 on their surface. These cells did not exhibit changes in their division rate or adhesive properties induced by low or high levels of expression of mCD24. When used as monolayer substrata for PNS and CNS neurons, however, neurite outgrowth was inhibited substantially compared with the exuberant growth observed on untransfected parental C6 cells. This effect was dependent on both neuronal age and $\mathrm{mCD} 24$ levels of expression on the monolayer. The inhibition could not be accounted for by a homophilic interaction of $\mathrm{mCD} 24$, because neonatal neurons isolated from a mCD24-deficient mouse were also inhibited. We therefore propose that in the nervous system, mCD24 
modulates neurite outgrowth via a heterophilic interaction with a developmentally regulated neuronal receptor.

\section{MATERIALS AND METHODS}

Construction of $m C D 24$ expression vectors. For transfection, the $\mathrm{pRC} /$ CMV vector (Invitrogen, San Diego, CA) that contains the bacterial neomycin (neo) resistance gene under the control of the SV40 promoter was chosen. The vector was cut in the polylinker at the unique site HindIII. A full-length mCD24 cDNA was excised from pSEX62.2 vector as a $B a m \mathrm{HI}-B a m \mathrm{HI}$ fragment. Both $\mathrm{pRC/CMV}$ and $\mathrm{mCD} 24$ cDNA were made blunt with T4 DNA polymerase and ligated.

The retroviral vector used in this study was prepared with different vectors provided by Dr. J. Major (Washington University School of Medicine, St. Louis, MO). Briefly, this vector expressed the upstream gene (mCD24) from the Rous sarcoma virus long-terminal repeat, whereas the downstream gene $(\beta-g a l)$ was expressed from the encephalomyocarditis virus internal ribosome entry site (Ghattas et al., 1991). cDNA coding for mCD24 was inserted in the sense orientation using the 1704 vector Bam HI unique site.

C6 transfection and infection. The rat $\mathrm{C} 6$ glioma cell line (ATCC CCL107) was cultured in DMEM (Gibco, Cergy Pontoise, France) containing $10 \%$ fetal calf serum (DMEM-FCS). Fifty micrograms of $\mathrm{pRC} /$ CMV plasmid were transfected by electroporation into $5 \times 10^{6}$ cells suspended in $0.8 \mathrm{ml}$ of DMEM-FCS in a $0.4 \mathrm{~cm}^{3}$ cuvette (Eurogentec, Seraing, Belgium) and pulsed with $1800 \mu \mathrm{F}$ at $250 \mathrm{~V}$. Stable transfectants were selected in G418 ( $800 \mu \mathrm{g} / \mathrm{ml}$ of active drug) and cloned by limiting dilution. The isolated clones were probed for surface expression of the mCD24 glycoprotein by fluorescence-activated cell sorter (FACS) analysis using the rat anti-mCD24 mAb clone 194-563 (Rougon et al., 1991).

To produce retroviral infectious particles, the viral producer cell line Psi 2 was transfected using electroporation as above, and viral particles were produced as described by Price et al. (1987). Forty-eight hours after infection, $\mathrm{C} 6$ cells were sorted with a Becton Dickinson (Labotechnia, Marseille, France) cell sorter, and the $100 \%$ mCD24-positive population that was collected was named A6.

Cell division rate. Individual wells of a 96-well tissue culture plate were inoculated with $0.2 \mathrm{ml}$ of medium containing concentrations of cells ranging from $10^{3}$ to $10^{4}$ cells/well and incubated for $24-72 \mathrm{hr}$. 3-(4,5dimethylthiazol 2-yl)-2,5-diphenyl tetrazolium bromide (Tetrazolium MTT; Sigma, Saint Quentin Fallavier, France) was prepared as a solution of $4 \mathrm{mg} / \mathrm{ml}$ in DMEM without phenol red, stored in the dark at $4^{\circ} \mathrm{C}$, and filter-sterilized. Before use it was diluted 1:4 in DMEM without phenol red, and $0.1 \mathrm{ml}$ was added to each well. 'The plates were covered with foil and incubated at $37^{\circ} \mathrm{C}$ for an additional $3 \mathrm{hr}$. Subsequently, the supernatants were removed by inverting the plates, and $0.1 \mathrm{ml}$ of propanol was added to extract and solubilize the formazan. After vigorous shaking, the plates were transferred to a microplate reader, and the optical density of each well was measured using a $550 \mathrm{~nm}$ wavelength (Miller et al., 1991). Cell division rate was expressed as the ratio of the variation in the total number of cells within $24 \mathrm{hr}$.

Cell aggregation assay. Subconfluent monolayers of transfected or parental cells were detached from the culture dishes in $10 \mathrm{ml}$ of PBS/ $1 \mathrm{~mm}$ EDTA (Gibco) (10 min at room temperature) and dissociated into single cells by gentle pipelting with a Pasteur pipetle. After an additional wash in EDTA, the cells were resuspended in complete medium at $2 \times 10^{6}$ cells/ml. For quantification of aggregate formation, they were transferred to $15 \mathrm{ml}$ polystyrene tubes (Falcon, Labotechnia, Marseille, France) that had been coated with FCS for $1 \mathrm{hr}$ at $37^{\circ} \mathrm{C}$. The test was performed by incubating $2 \mathrm{ml}$ aliquots of the cell suspension at $37^{\circ} \mathrm{C}$ in a $7.5 \% \mathrm{CO}_{\text {? }}$. atmosphere without agitation. Aliquots were withdrawn at 15 min intervals after mixing by gentle inversion, and the remaining single cells were counted in a hematocytometer (Gennarini et al., 1991).

Preparation of dissociated retinal cells. Retinae from embryonic and neonatal Wistar rats were collected in calcium- and magnesium-free Earle's balanced salt solution (CMF) (Gibco, Glasgow, UK), transferred to $5 \mathrm{ml}$ papain (Lorne Laboratories, Twyford, UK) $(10 \mathrm{U} / \mathrm{ml}$ ) in a HEPES-buffered salt solution containing cysteine (Leifer et al., 1984), and incubated at $37^{\circ} \mathrm{C}$ for 15 min. The tissue was then transferred to 0.5 $\mathrm{ml}$ CMF/DNase (Type I, $50 \mu \mathrm{g} / \mathrm{ml}$; Sigma, Poole, UK) and triturated to give a single-cell suspension by several passes through a small-bore pipette tip. The mixed retinal cell suspension from E14-18 rats was plated at a concentration of $100,000 \mathrm{cells} / \mathrm{ml}$.

Retinal ganglion cells (RGCs) were purified from E20-P4 retinal cell suspensions by immunopanning for Thy-1-positive cells using mAb Ox7, as described by Shewan et al. (1995).
Preparation of dissociated dorsal root ganglion (DRG) neurons. Dorsal root ganglia were dissected out from embryonic, postnatal, and adult Wistar rats or C57BL/6 mice, collected in Ham's F-12 medium (Gibco), and trimmed closely to remove the attached roots. Embryonic and nconatal DRG tissue was enzymatically treated, and cells were dissociated as described for retinal tissue (see above). The dissociated cells were then diluted to a concentration of $5000 / \mathrm{ml}$ in modified Bottenstein and Sato's tissue culture medium containing $2 \%$ fetal calf serum (BSF2) in F-12 supplemented with nerve growth factor (NGF) $(100 \mathrm{ng} / \mathrm{ml})$.

Adult ganglia were incubated at $37^{\circ} \mathrm{C}$ for $3 \mathrm{hr}$ in $0.125 \%$ collagenase (Sigma) in F12, as described by Lindsay (1988), transferred to papain solution, and incubated for an additional $15 \mathrm{~min}$, as described above, washed in F12, and triturated in $1 \mathrm{ml}$ of fresh BSF2. The cell suspension was spun through a $2 \mathrm{ml}$ cushion of $15 \%$ bovine serum albumin (fatty acid-free; Sigma) in F-12 to rcmovc myelin debris, and the pelleted cells were resuspended in BSF2 containing NGF $(100 \mathrm{ng} / \mathrm{ml})$ to a cell concentration of $2000 / \mathrm{ml}$

Neuronal cultures on $\mathrm{C} 6$ cell monolayers. C 6 rat glioma cells were passaged using $0.125 \%$ trypsin (Sigma) in EDTA (Sigma), collected in an equal volume of conditioned medium, and spun at $200 \times g$. The pellet was resuspended in conditioned medium, and cells were plated in DMEMFCS. When the different C6 clones formed monolayers, $0.25 \mathrm{ml}$ of neuronal cell suspensions was pipetted into each well and cultured for a period of 18-24 hr before fixation and immunostaining.

Antibodies. Rabbit anti-GAP43 antiserum from Graham Wilkin (Imperial College, London) was used as a marker for cultured neurons at a dilution of 1:1000 (Bedi et al., 1992). Where mixed retinal cultures were used, we confirmed by double immunolabeling that Thy-1-positive RGCs were the only GAP43-positive cells present (data not shown). To test that the underlying transfected/infected $\mathrm{C} 6$ cells expressed mCD24, the antiGAP43 antibodies were combined in double-immunostaining with a rat $\mathrm{mAb}$ to mCD24 (H194-563), at a dilution of 1:100.

Immunohistochemistry. For simple mCD24 immunolabeling, cells grown overnight on poly-L-lysine-treated coverslips were incubated with the rat antibody specific to mCD24 and revealed with fluorescein rabbit anti-rat IgG fragments (Immunotech, Marseille, France). Cells were then fixed with cold $5 \%$ acetic acid/95\% ethanol for 1 min. Retina and DRG sections were fixed with $4 \%$ paraformaldehyde, and the immunolabeling was carried out as described above.

Cultures to be labeled solely with neuronal markers were fixed at room temperature for at least $10 \mathrm{~min}$ in $2 \%$ paraformaldehyde in PBS and permeabilized in $100 \%$ methanol at $-20^{\circ} \mathrm{C}$ for $3 \mathrm{~min}$. The labtek slides were incubated first at room temperature for $2 \mathrm{hr}$ (or overnight at $4^{\circ} \mathrm{C}$ ) in the primary antibodies, and then antibody-binding was revealed with the Texas red-biotin-streptavidin system ( $\Lambda$ mersham, Buckinghamshirc, UK).

For mCD24/GAP43 double-immunolabeling, cultures were paraformaldehyde-fixed as above and then first incubated in the anti-mCD24 mAb, revealed by the Texas red-biotin-streptavidin system (Amersham). Cells were then permeabilized with $100 \%$ methanol at $-20^{\circ} \mathrm{C}$ and incubated with GAP43 antiserum revealed by an anti-rabbit fluoresceinconjugated antibody.

All slides were mounted in glycerol containing diazabicyclo[2,2,2]octane (Sigma) to prevent fading of fluorescence and were examined with a Zeiss Axiophot microscope equipped with epifluorescence.

Cell counts. Counts were made under fluorescence optics of all GAP43positive neurons attached to the undcrlying $\mathrm{C} 6$ cell monolayers and of those with neurites of more than three cell-body diameters (cbd) in length. The proportion of neurite-bearing cells was expressed as a percentage of the total number of attached cells in duplicate cultures, averaged for at least three separate preparations of each neuronal type \pm SEM, statistically evaluated by the Student's two-tailed $t$ test.

Measurement of total neurite outgrowth/neuron by P1 DRG neurons of homozygous and heterozygous $\mathrm{mCD} 24$ mutant mice. Cultures of dissociated DRG cells from homozygous and heterozygous mCD24 mutant mice were grown on different monolayers for $18 \mathrm{hr}$ in BSF2. Neurite lengths were quantified after anti-GAP43 immunolabeling of the neurons with a Zciss Axiophot microscope equipped with epifluorescence and a COHU 4700 camera. Quantification was made using a custom macro written for Optimas 4.1 software package (Bioscan, Washington, D.C.) running on a $\mathrm{PC} 486 \mathrm{DX} 66$ computer with a $\mathrm{PC}$ Vision plus frame grabber (Imaging Technology, France). Neurite-length curves were generated in Stat-View (Microsoft) and plotted in Cricket-Graph (Microsoft) as described (Chang et al., 1987). Only neurites that emerged from an isolated neuron and that did not contact other neurites or cells were considered. Total 
Figure 1. Flow cytometric analysis of parental C6 $(A), \mathrm{mCD} 24$-transfected $\mathrm{A} 4(B)$, and $\mathrm{E} 3(C)$ or infected $\mathrm{A} 6(D)$ rat glioma cell lines. A suspension of EDTA-treated cells was labeled with the mAb 193-563 specific to mCD24 (see Materials and Methods) and analyzed with an FACS-Scan (Bec ton Dickinson), and the number of cells was plotted as a function of fluorescence intensity. A6 cells $(D)$ expressing a fluorescence intensity higher than the threshold (dashed line) were sorted to give a $100 \%$ mCD24-positive population.
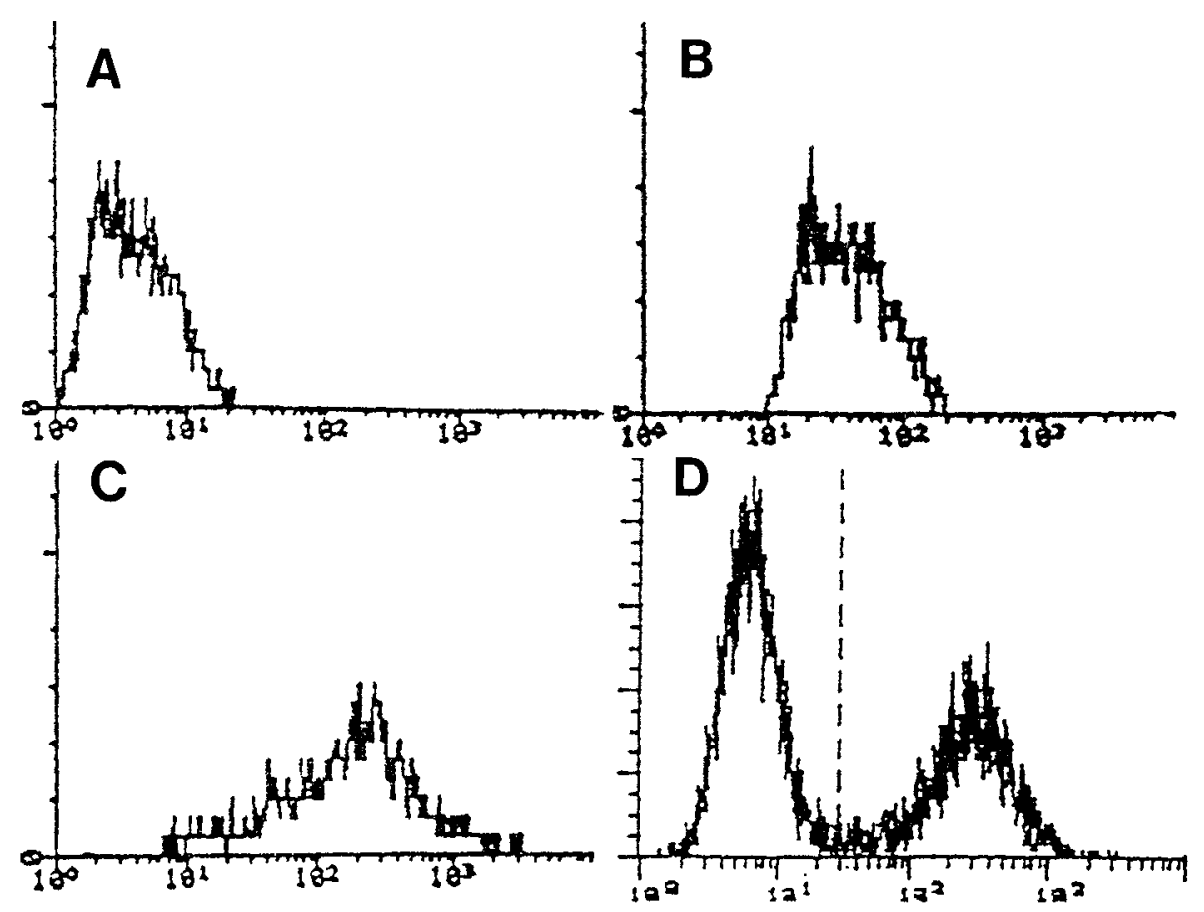

neurite lengths were quantified as the total extent of the arborization from the cell soma to the growth cone, including all branches.

\section{RESULTS}

\section{Expression of $\mathrm{mCD} 24$ by $\mathbf{C} 6$ cells}

$\Lambda$ construct encompassing the entire mCD24 cDNA coding sequence was cloned into the $\mathrm{pRC/CMV}$ plasmid downstream of the strong cytomegalovirus promotor. C6 cells were chosen for transfection on the following basis. (1) They do not normally express mCD24, (2) they readily express GPI-anchored molecules at their cell surface, (3) they have a glial phenotype, a cell type normally contacted by neurons, and (4) they rapidly form confluent monolayers.

Of the 21 G418-resistant, independent transfectants, two (A4 and E3) expressed high levels of the $\mathrm{mCD} 24$ glycoprotein at the cell surface. FACS analysis indicated that the average level of expression on E3 cells was approximately twice that of A4 (Fig. $1 B, C)$; however, these clones showed a high tendency to lose mCD24 expression after several passages. To overcome this difficulty and to make sure that the observations made on individual clones were indeed attributable to mCD24 expression, we prepared a retrovirally infected cell line named $\wedge 6$. This cell line was stable after several passages and consistently exhibited the highest level of expression (Fig. 1D).

To assess that all cells were expressing mCD24, A4 and E3 clones and the A6 cell line were grown on coverslips and labeled by immunofluorescence with the anti-mCD24 mAb. Although the intensity of immunolabeling varied between cells of a given clone, as already indicated by the broadness of the peak obtained by FACS, most of the cells were positive, as shown by the subconfluent monolayer in Figure $2 \mathcal{A}$. The presence of a GPI anchor for $\mathrm{mCD} 24$ in transfected cells was verified by incubating cells on a coverslip with $0.05 \mathrm{U} / \mathrm{ml}$ phosphatidylinositol phospholipase $\mathrm{C}$ (PI-PLC). This treatment resulted in the disappearance of fluorescence intensity after labeling of the cells (data not shown). To test whether the transfection/infection of the C6 cells with mCD24 cDNA affected the cell surface expression of other molecules, we immunolabeled A6 and parental C6 cells with an antibody against the neural cell adhesion molecule, NCAM, a member of the immunoglobulin superfamily. Figure $2 C, D$ shows that the expression of NCAM does not change after cell transfection. The expression of matrix molecules, such as laminin and fibronectin, is also unaffected by the transfection/infection process (data not shown).

\section{Cell division rate of $\mathrm{mCD} 24-$ transfected $\mathbf{C 6}$ cells}

Because mCD24 is normally expressed only on postmitotic neuroblasts, we tested the effect of ectopic expression by $\mathrm{C} 6$ cells on their cell division rate. Cell division rates of parental and $\mathrm{mCD} 24$ cDNA-transfected $\mathrm{C} 6$ cells were measured using a colorimetric assay with MTT after plating different concentrations of cells (see Materials and Methods). The small differences in ccll division rates of C6 parental cells (mean $2.8 \pm 0.21$ SEM; ratio of total cell number at $24 \mathrm{hr}$ over total at time 0 ), and the A4 and E3 mCD24-transfected clones $(2.5 \pm 0.22$ and $2.5 \pm 0.26$, respectively) were not statistically significant.

\section{Influence of $\mathrm{mCD} 24$ on $\mathbf{C 6}$ cell aggregation}

On the basis of experiments using mCD24 purificd from lymphocytes and coated on latex beads, $\mathrm{mCD} 24$ glycoprotein has been implicated in homophilic cell-cell adhesion (Kadmon et al., 1992). We therefore investigated whether expression of $\mathrm{mCD} 24$ conferred new adhesive properties on the transfected cells by comparison with the parental C6 cell line. Single-cell suspensions were prepared by trituration in the presence of EDTA, a treatment that leaves cell surface mCD24 intact; cells were resuspended in complete medium and incubated for varying times in bacteriological tubes that do not allow cell attachment. Under these conditions, the parental cell line was able to aggregate slowly ( $50 \%$ in $60 \mathrm{~min}$ ) (Fig. 2). This aggregation was abolished completely in the presence of EDTA. Transfectants A4 and E3 displayed similar kinetics of cell-cell aggregation compared with that of parental C6 cells (Fig. 3), which was also EDTA-sensitive. 

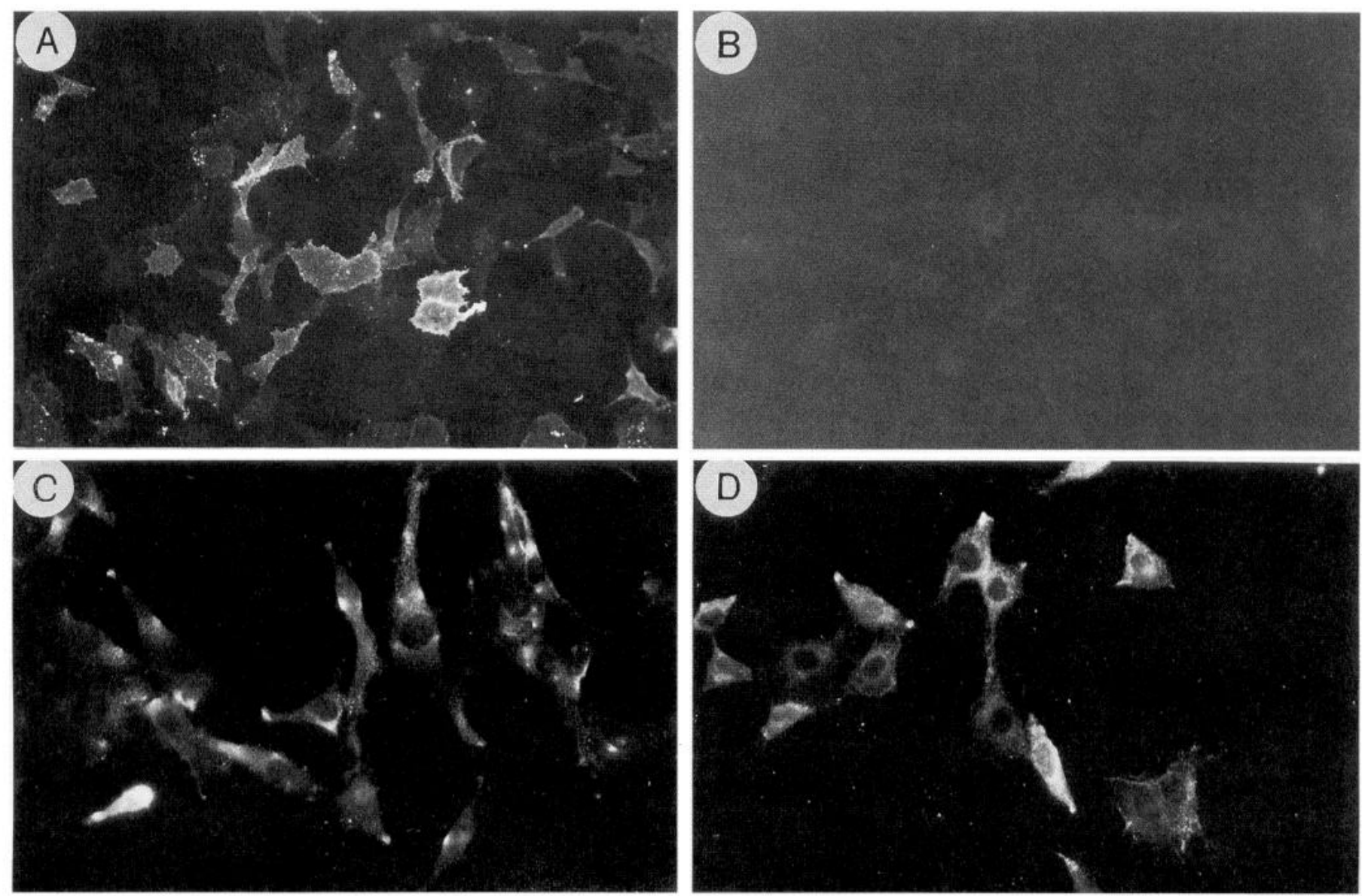

Figure 2. Fluorescent photomicrographs showing the expression of mCD24 $(A)$ after retroviral infection of C6 rat glioma cells that normally do not express mCD24 $(B)$ with the cDNA for mCD24. The expression of other cell surface molecules, including NCAM, is not affected by the infection process, because both infected $(C)$ and control $(D)$ cells are equally immunopositive. $A, B, 194.563 ; C, D$, NCAM. Scale bar, $40 \mu \mathrm{m}$.

\section{Expression of mCD24 by RGCs and DRG neurons in vivo and in vitro}

To examine the in vivo expression of $\mathrm{mCD} 24$, prefixed cryosections of mouse brain and spinal cord with attached DRGs taken at various developmental ages, from early embryonic to adult, were immunostained with anti-mCD24 antibody. Within the retina, the RGCs and optic fiber layers were strongly positive by E12.5, as was the optic nerve (Fig. $4 A$ ), at a time when axons have begun to exit the eye (Silver, 1984). Expression remained strong on RGC axons throughout the embryonic optic nerve pathway until the neonatal period, when immunolabeling intensity diminished to reach negligible levels by P15 (data not shown). In adult mice, the optic axons were completely mCD24-negative (Fig. 4B). DRGs were CD24-positive as early as E13, and expression was retained at E16 (Fig. 4C). The glycoprotein was downregulated from P2 to negligible levels at P10 (Fig. 4D).

Dissociated cultures of mouse retina and DRG neurons grown on merosin were tested for mCD24 expression. More than $90 \%$ of both RGCs and DRG neurons were immunopositive for mCD24 at embryonic and neonatal stages (Fig. 5A-D). Thus, GAP43positive RGCs from E17 mice express mCD24 (Fig. 5A,B, small arrows) from their soma to the tips of their growth cones. Other GAP43-negative retinal cells were also labeled with mCD24 (large arrows). A similar expression pattern was observed on DRG neurons, because most of the GAP43-positive neurons of E17 mice express mCD24 over their entire surface (Fig. $5 C, D$ ).

\section{Inhibitory effect of mCD24 on neurite outgrowth in vitro}

The growth responses, revealed by GAP43 immunolabeling, of different ages of rat RGCs and DRG neurons cultured on C6 rat glioma cell monolayers are shown in Figure 6. Early embryonic RGCs (E14) extended lengthy processes on the parental, mCD24negative C6 cells (Fig. $6 A$ ). No significant difference could be observed when these RGCs were grown over the mCD24expressing E3 cell monolayer (Fig. 6B). In contrast, neonatal RGCs that grew lengthy neurites on parental cells (Fig. $6 C$ ) were substantially inhibited on E3 monolayers (Fig. 6D). Thus, neurite outgrowth by RGCs seemed to be inhibited by mCD24 only at later stages of development.

In common with RGCs, early embryonic DRG neurons regenerated extensively, not only on parental C6 monolayers (Fig. $6 E$ ) but also over E3 monolayers (Fig. $6 F$ ). In the case of neonatal and adult DRG neurons, however, neurite outgrowth was substantially reduced on the mCD24-expressing cell lines (Fig. $6 G-J$ ).

Figure 7 shows the magnitude of inhibition for different ages of rat RGCs and DRG neurons. This reveals clearly that for both classes of neurons, neurite outgrowth by the early embryonic cells was undiminished on CD24-expressing C6 cells. In contrast, compared with the extent of outgrowth on control C6 cells, there was striking inhibition of neurite outgrowth by neonatal RGCs $(75 \%)$ and DRG neurons $(62 \%)$ and by adult DRG neurons $(57 \%)$. In Figure 7 , the data were pooled for the different 
Figure 3. Aggregation kinetics of mCD24 transfectants and control C6 cells (see Materials and Methods). The results are expressed as percentage of single cells at each time point compared with the number of single cells at time 0 . Values shown are the mean \pm SEM for four independent experiments. Cell viability, as judged by trypan blue exclusion, remained $>90 \%$ throughout the experiment.

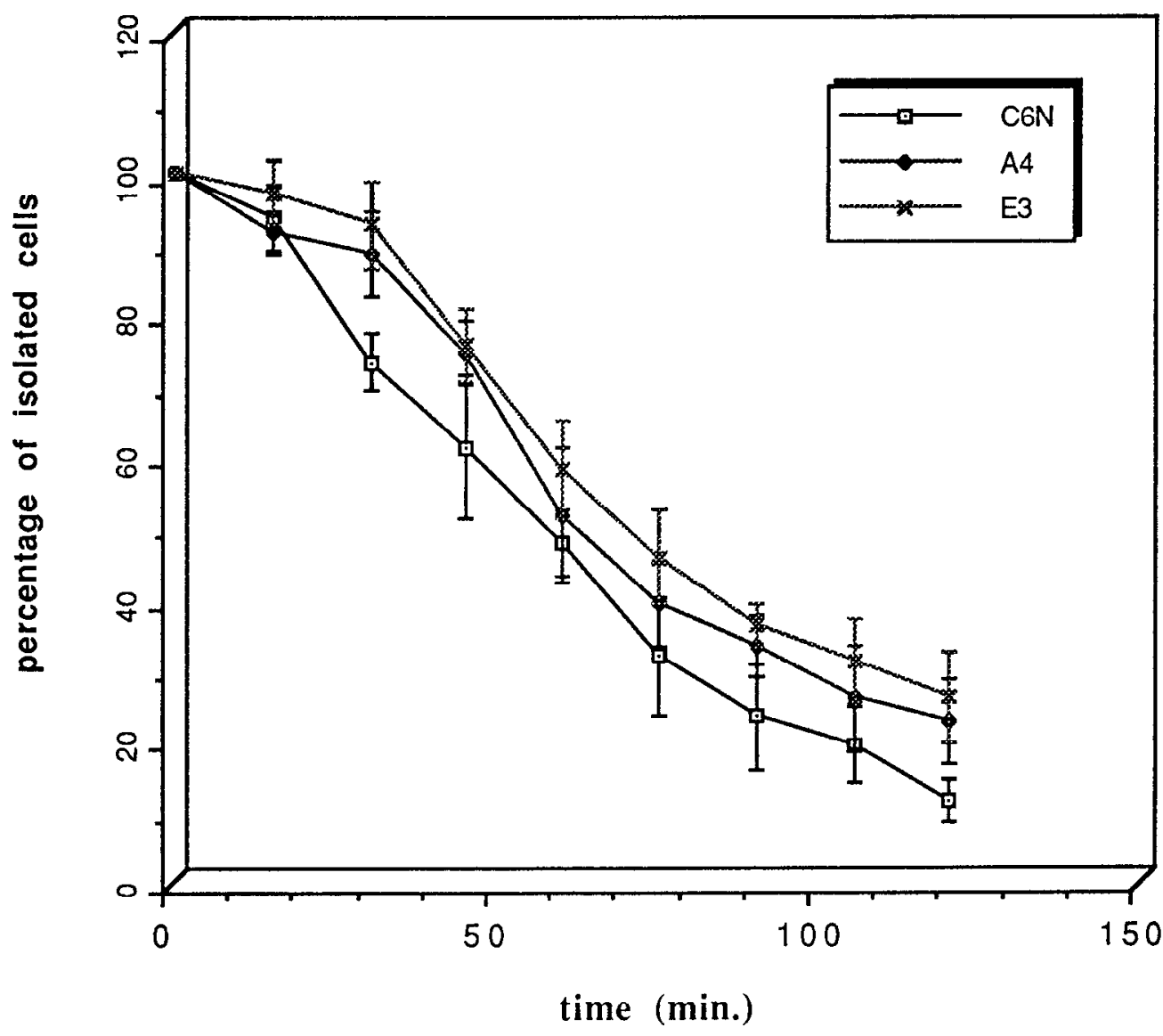

CD24-expressing lines; however, when the response to individual cell lines was analyzed separately in the case of neonatal RGCs (Fig. $7 A$, inset), the extent of inhibition of neurite outgrowth was shown to be proportional to the levels of CD24 expression (i.e., A4 $<$ E3 $<$ A6).

\section{Effect of mCD24 on neurite outgrowth by mCD24-negative neurons}

The above experiments imply clearly that expression of $\mathrm{mCD} 24$ by neurons is of itself insufficient to evoke an inhibitory response and that a heterophilic receptor may be involved. To test this possibility, cultures were prepared from neurons obtained from a mouse homozygous for the mCD24 gene deletion (Wenger et al., 1995). All the data presented here were obtained with DRG neurons taken at $\mathrm{P} 1$, a stage in the rat at which consistent inhibition of DRG neurite outgrowth was observed (see above). Four independent experiments were made in parallel with DRG from either homozygous $(-/-)$ or heterozygous $( \pm)$ pups of the same litter. Analyses were made after $18 \mathrm{hr}$ of culture and GAP-43 immunolabeling, and the average total neurite output per neuron (i.e., the total length of neurites emanating from each cell body) was estimated by image analysis. When the responses of $\mathrm{mCD} 24$-negative and -positive neurons cultured on monolayers of C6 or A6 cells were compared, no differences were detected in their behavior (Fig. 8). Nevertheless, the total neurite output per neuron was reduced substantially, regardless of CD24 expression, when grown on mCD24-expressing cells. Thus, Figure 8 shows that for neurons grown on A6 monolayers, $50 \%$ of the neurite output has a mean value of $\sim 350 \mu \mathrm{m}$ on control $\mathrm{C} 6$ cells com- pared with only $150 \mu \mathrm{m}$ on mCD24-expressing A6 cells, an inhibition of $>60 \%$.

\section{DISCUSSION}

An increasing number of molecules have been implicated in the control of axon growth and guidance in development by their ability to inhibit or repel neurite outgrowth in vitro (for review, see Keynes and Cook, 1995). In pathfinding, axon growth inhibition is probably at least as important as the promotion or support of axon extension, because inhibitory boundaries enable axons to reach appropriate destinations and to know when to stop. In accordance with such an important role, candidate inhibitory molecules show great variety in their patterns of expression and structure and include extracellular matrix glycoproteins such as tenascin and janusin (Bartsch et al., 1992; Wintergerst et al., 1993) and some proteoglycans (Snow et al., 1990, 1991); components of myelin such as myelin-associated glycoprotein (MAG) (Mukhopadhyay et al., 1994) and NI-35/250 (Caroni and Schwab, 1988a,b); soluble factors including the netrins (Kennedy et al., 1994; Sefarini et al., 1994) and collapsin (Luo et al., 1993), a member of the conserved semaphorin family (Kolodkin et al., 1993); and GPI-anchored molecules such as ELF-1 (Cheng et al., 1995), RAGS (Drescher et al., 1995), and Thy-1 (Tiveron et al., 1992).

In the present in vitro studies, we have examined several cellular interactions and possible functions of the developmentally regulated GPI-anchored glycoprotein, $\mathrm{mCD} 24$. In cells of the immune system, mCD24 has been ascribed a role in cell adhesion (Kadmon et al., 1992; Hahne et al., 1994). Although it lacks a transmembrane domain, $\mathrm{mCD} 24$ nevertheless may be able to trans- 

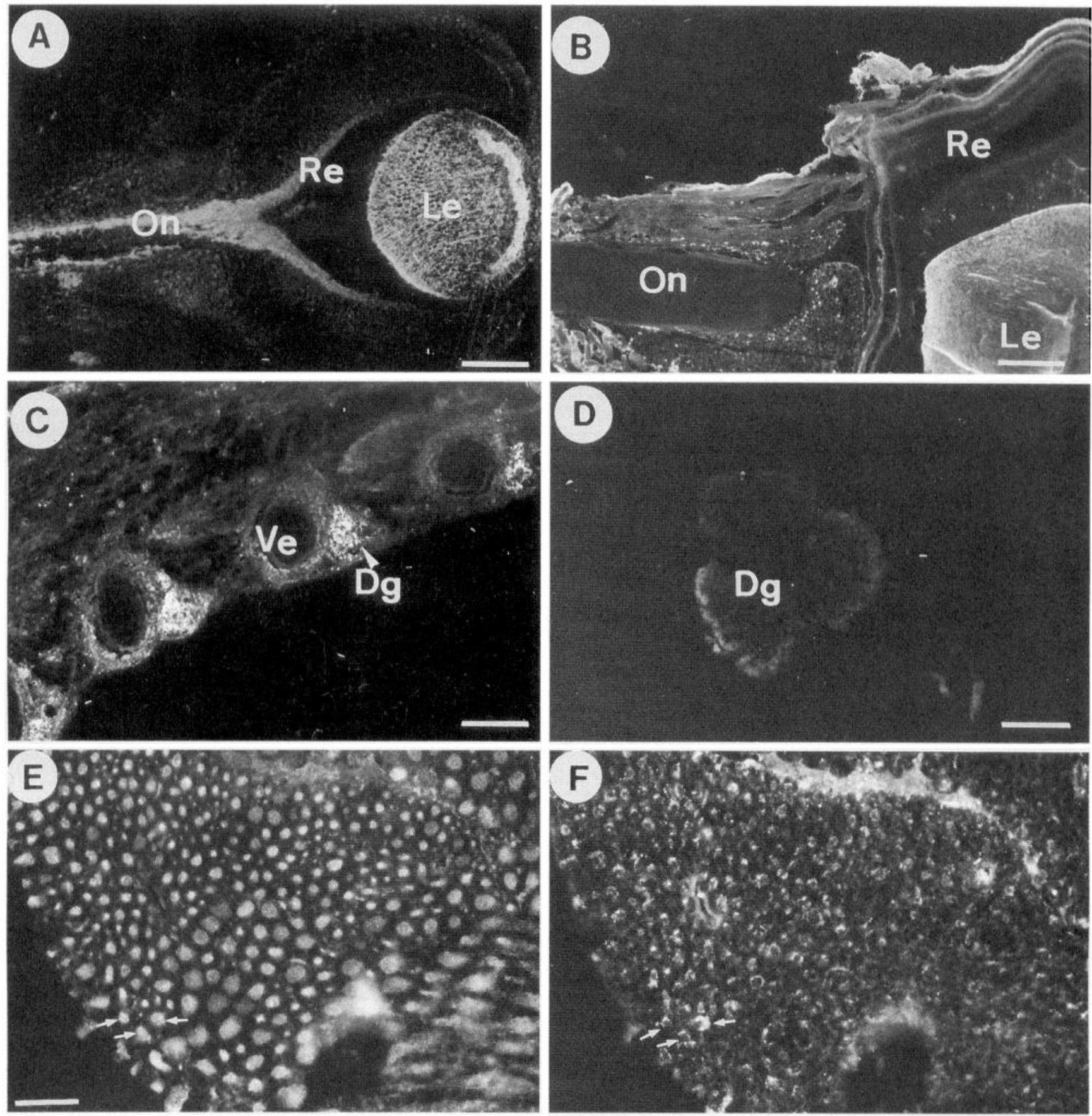

Figure 4. Expression of mCD24 in the mouse optic nerve projection pathway and DRG. $A, B$, Horizontal sections of head were stained with anti-mCD24 antibodies at E12.5 $(A)$ and P30 $(B)$. Immunoreactivity of both neural retina and optic nerve was observed in the embryo and disappeared in the young adult. Note that the lens appeared to be mCD24-positive, but this tissue was also labeled in controls, indicating a nonspecific reaction. $C, D$, Sagittal section of DRG stained with anti-mCD24 antibodies at E16.5 $(C)$, and section of dissected P30 DRG $(D)$. In the embryo, DRG neurons were positive for mCD24 expression and immunonegative in the adult. In lumbar DRG of an adult mouse that had undergone sciatic nerve lesion $8 \mathrm{~d}$ before removal, GAP43-positive neurons (for example, arrows in $E$ ) also express mCD24 (complementary arrows in $F$ ). $E$, GAP43; $A-D, F, 194.563 . R e$, Retina; Le, lens; $O n$, optic nerve; $V e$, vertebrae; $D g$, dorsal root ganglion. Scale bars: $100 \mu \mathrm{m}$ in $A-C ; 1 \mathrm{~mm}$ in $D$.

duce signals, because it coprecipitates with a protein kinase activity in B cells (Stefanova et al., 1991), and incubation of B cells with mAbs to CD24 results in the tyrosine phosphorylation of several cytoplasmic proteins. Hitherto, the role of mCD24 in the nervous system has been largely unexplored. The possibility that it may be a novel neural cell adhesion molecule prompted us to test its effects on neurite growth by both CNS and PNS neurons in vitro. Interestingly, our results show that when stably expressed by the C6 rat glioma cell line and used as a monolayer substrate for cultured neurons, mCD24 inhibits neurite outgrowth in a concentration-dependent manner. This inhibitory response is dependent on the age of the neurons and does not operate via a 

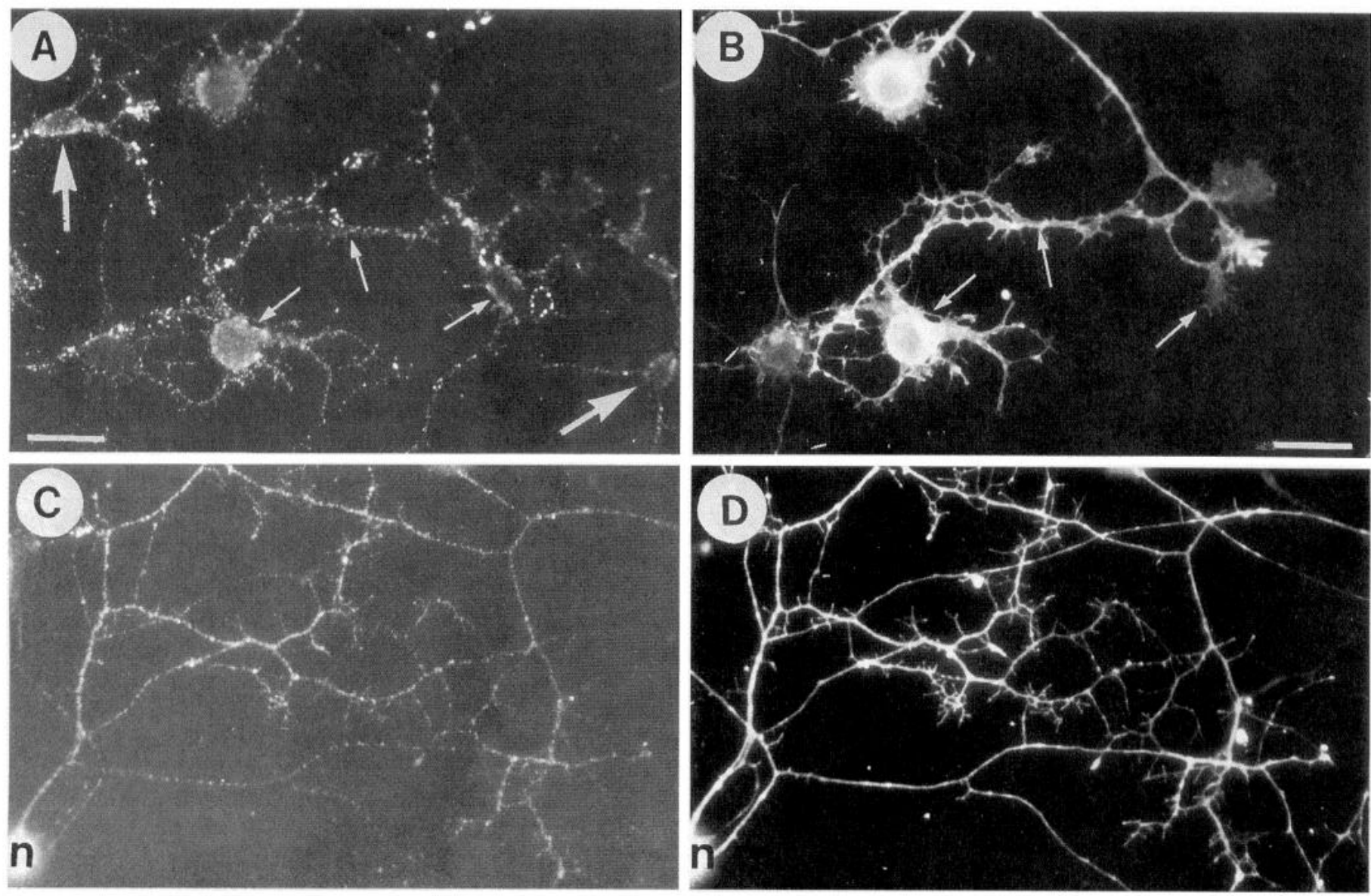

Figure 5. Photomicrographs showing mCD24 expression by immature mouse retinal cells and DRG neurons in vitro. Double-immunolabeling with GAP43 and mCD24 antibodies revealed that RGCs in E17 retinal cultures expressed mCD24 from the soma to the tips of the growth cones $(A, B$, small arrows). Some E17 retinal cells that expressed mCD24 were GAP43-negative (large arrows). Double-immunolabeled E17 DRG neurons also exhibited mCD24 expression in their entirety, from soma to growth cones ( $C, D: n$, neuronal cells body). $A, C, 193.563 ; B, D, \mathrm{GAP} 43$. Scale bar, $25 \mu \mathrm{m}$.

homophilic mechanism, because neurite outgrowth by immature mCD24-positive neurons and neurons isolated from a mCD24deleted mouse were similarly affected.

\section{Characterization of mCD24-expressing glial cells}

We have developed a range of C6 rat glioma cells expressing the GPI-anchored mCD24 glycoprotein. As judged by quantitative immunofluorescence analysis, the transfected clones A4 and E3 and the cell-sorted retrovirally infected A6 line all express mCD24 at the cell surface but at different levels; thus, A4 $<$ E3 $<$ A6. The absence of specific homophilic adhesive properties conferred on the transfected cells by mCD24 contrasts with data reported by Kadmon et al. (1992). Thus, mCD24 may have different roles in the immune system, where it is heavily glycosylated, and in the brain, where glycosylation is less extensive.

\section{Inhibition of neurite outgrowth by mCD24 is age- dependent and mediated by a heterophilic receptor}

Neonatal RGCs and neonatal and adult DRG neurons were substantially inhibited from extending processes over monolayers of mCD24-expressing C6 cells. None of the available anti-mCD24 antibodies were able to disinhibit this effect. This was not surprising, however, because all of these antibodies are known to be directed against a dominant epitope composed of the GPI anchor and an arginine residue in the C-terminal region of the peptide (Rougon et al., 1991; Nédelec et al., 1992). Nevertheless, other lines of evidence exist in favor of a direct effect of mCD24 in mediating the inhibition of neurite outgrowth. First, inhibition was obtained with one infected and two different transfected clones expressing mCD24. Second, inhibition was more pronounced as the level of $\mathrm{mCD} 24$ expression by the underlying $\mathrm{C} 6$ cells increased. Third, as judged by immunolabeling, expression of other cell surface proteins such as NCAM was not perturbed in the presence of $\mathrm{mCD} 24$.

Unlike their more mature counterparts, early embryonic RGCs and DRG neurons failed to respond to $\mathrm{mCD} 24$, regardless of the level expressed on the underlying monolayer. This raises an important question concerning the mode of interaction of neurons with $\mathrm{mCD} 24$. Thus, the age-dependent response exhibited by neurons expressing comparable levels of surface mCD24 suggests that a homophilic interaction of neuronal $\mathrm{mCD} 24$ is not involved in the inhibition of neurite outgrowth. This implicates a heterophilic mode of interaction of mCD24 expressed by the monolayer with an unknown neuronal receptor. This conclusion is supported further by the finding that neurite outgrowth by DRG neurons from mice homozygous for mCD24 gene deletion was also inhibited when these neurons were plated on monolayers of mCD24-expressing C6 cells. The nature of this putative heterophilic receptor is unknown. Recent studies on mCD24 suggest P-selectin may be a ligand/receptor in immune tissue (Sammar et al., 1994). In addition, mCD24 (nectadrin) interacts with the L1 glycoprotein on a neuronal cell line and activates the signal transduction pathway of L1 (Kadmon et al., 1995). Such studies suggest that mCD24 may have other functions in 

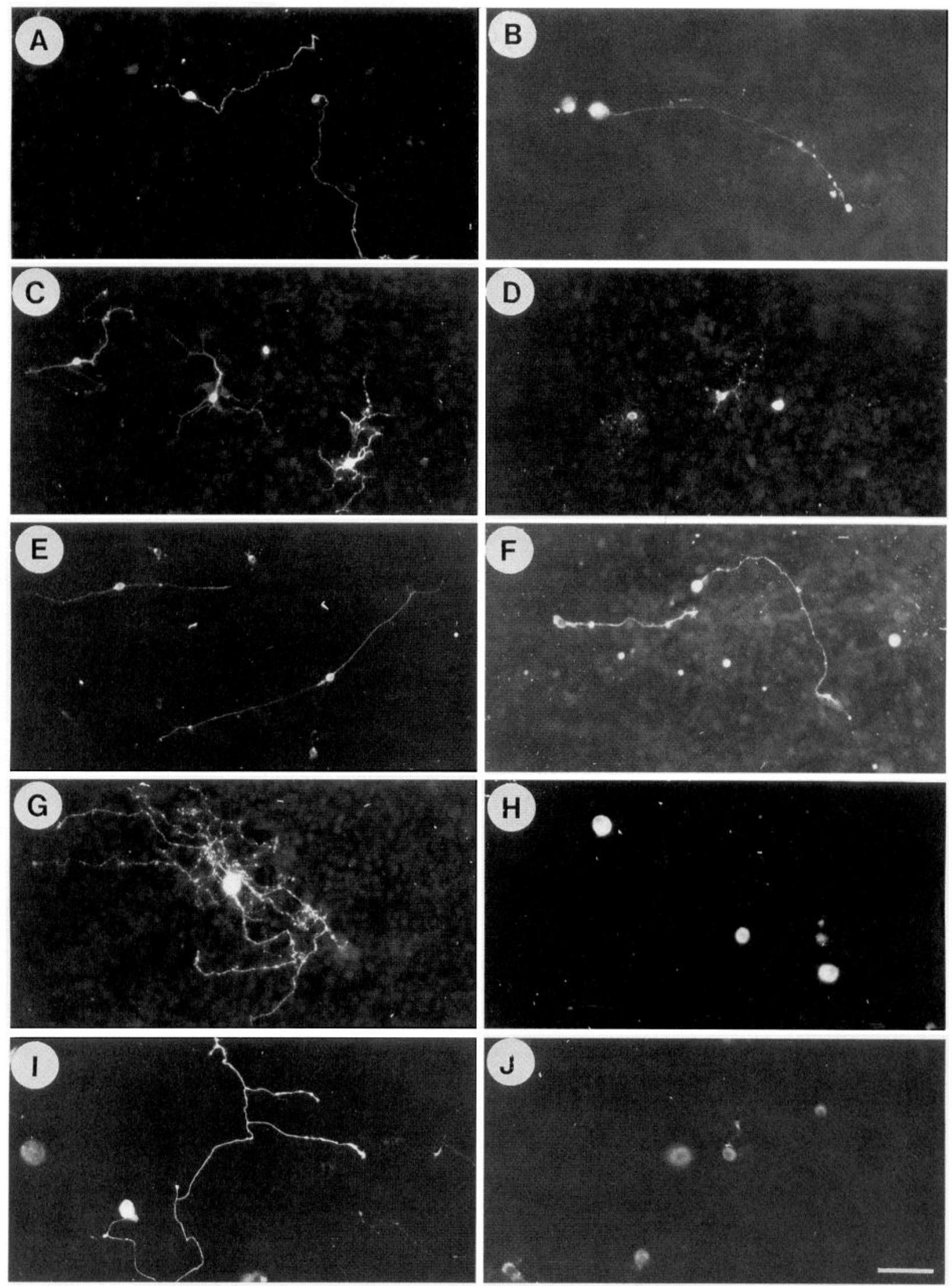

Figure 6. Fluorescent photomicrographs showing the neurite outgrowth responses of early embryonic, neonatal, and adult neurons cultured on monolayers of parental and mCD24 cDNA-transfected/infected C6 cells. E14 RGCs extended long neurites on both C6 cells $(A)$ and E3 cells $(B)$. P1 RGCs, however, were substantially inhibited from extending neurites on E3 cells $(D)$ when compared with their growth on C6 cells $(C)$. Similarly, E14 DRG neurons grew extensively on both $\mathrm{C} 6$ cells $(E)$ and E3 cells $(F)$, whereas neonatal and adult DRG neurons, which regenerated long neurites on C6 cells ( $G$ and $I$, respectively), were markedly inhibited when cultured on A4 cells $(H)$ and A6 cells $(J)$, respectively. $A-I$, GAP43 antiserum; $J$, GAP43 mAb. Scale bar: $80 \mu \mathrm{m}$ in $A, C, D, F-J ; 40 \mu \mathrm{m}$ in $B ; 160 \mu \mathrm{m}$ in $E$. 

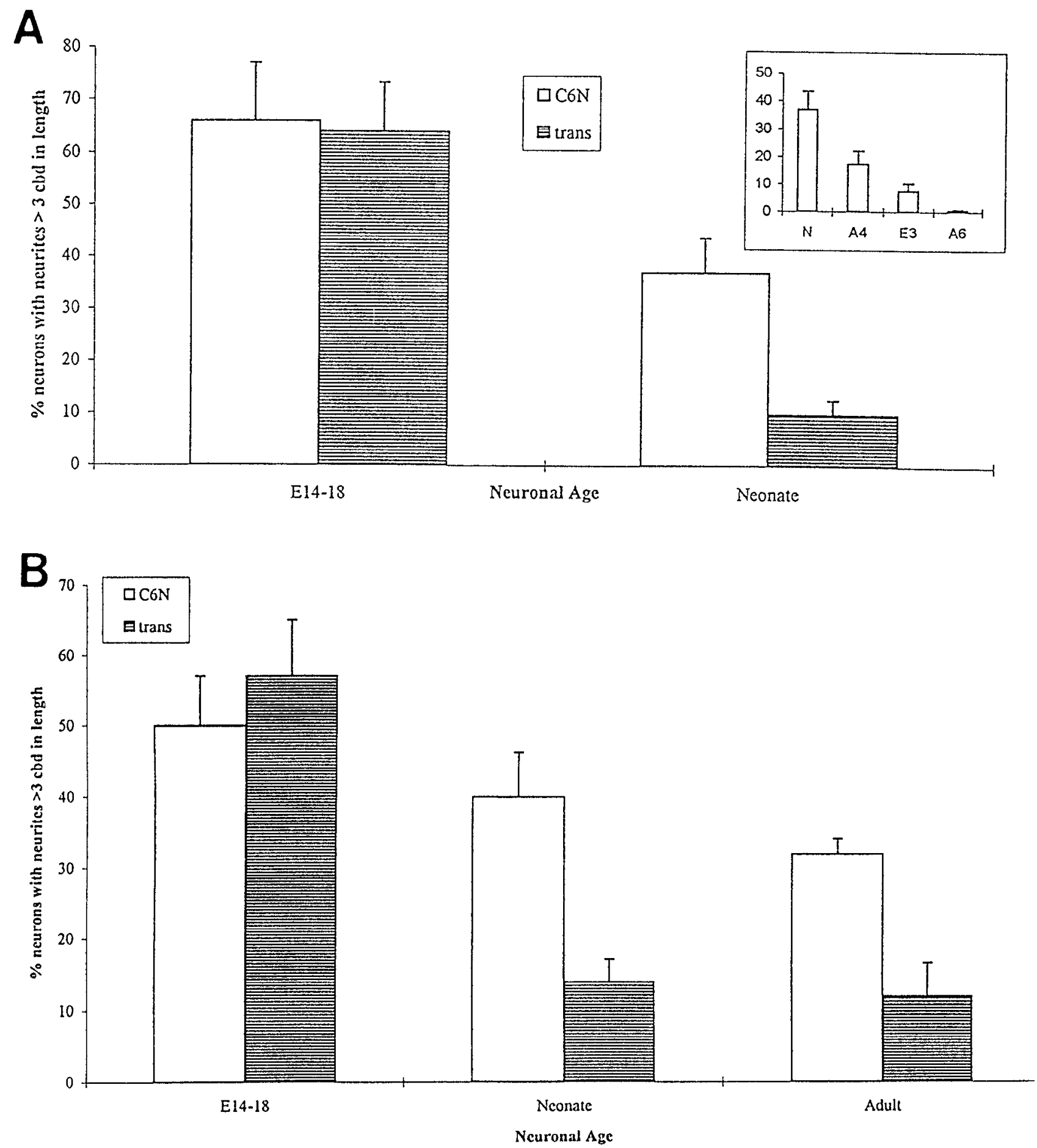

Figure 7. Histogram showing the neurite outgrowth responses of rat RGCs $(A)$ and DRG neurons $(B)$ of various developmental ages on mCD24-negative and -positive C6 cells. The abscissa shows the age of the neurons, whereas the ordinate represents the percentage of neurons that extended neurites of at least 3 cbd in length. Data for the various transfected/infected cell lines were pooled. E14-18 RGCs grew equally well on mCD24-negative and -positive cells $(A)$, but neonatal RGC neurite outgrowth was inhibited by $75 \%$ on transfected cells when compared with growth on C6 cells. The incidence of growth inhibition increased with an increasing level of mCD24 expression $(\mathrm{A} 4<\mathrm{E} 3<\mathrm{A} 6)$ on the transfected cells $(A$, inset). E14-17 DRG neurons also grew extensively on both $\mathrm{C6}$ and $\mathrm{mCD} 24$-positive cells $(B)$, but neurite outgrowth by neonatal and adult DRG neurons cultured on mCD24-positive cells was inhibited by 62 and $57 \%$, respectively, when compared with their outgrowth on C6 cells. Open bars symbolize untransfected C6 monolayers; hatched bars represent monolayers of transfected, mCD24-positive cells.

addition to one as an axon growth inhibitor. Thus, the expression of mCD24 by early embryonic neurons that fail to be inhibited by $\mathrm{mCD} 24$ may be attributable to functions of the glycoprotein yet to be defined. These findings resemble our earlier work, which demon- strated a sharp neuronal age-dependent inhibitory effect on neurite outgrowth by both DRG neurons and RGCs grown on unmyelinated neonatal (E18-P1) optic nerve cryosections (Shewan et al., 1993, 1995). Because mCD24 is strongly expressed in the immature but not 


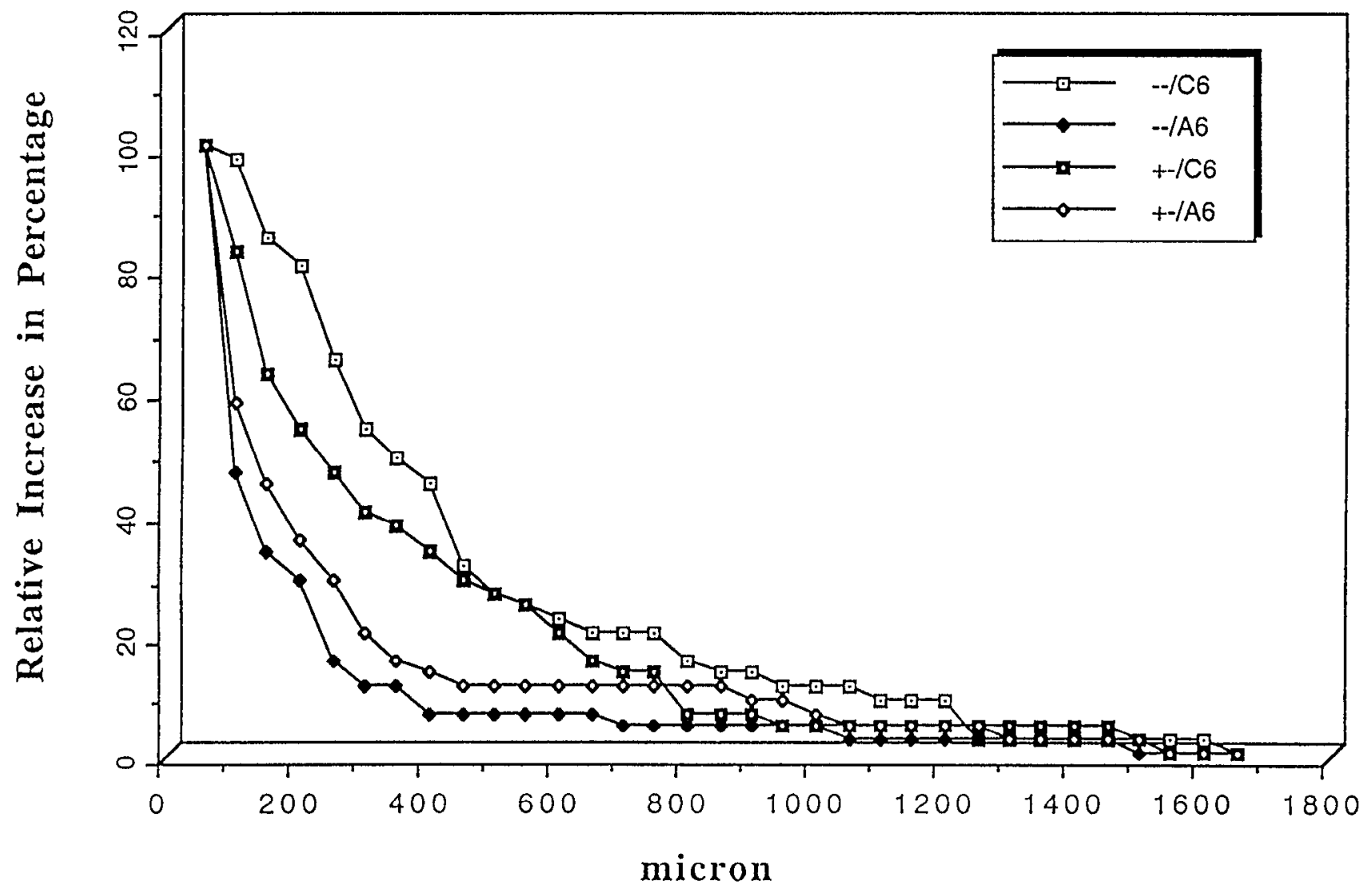

Figure 8. Cumulative frequency distribution plot of the total neurite lengths of DRG neurons after 18 hr on different monolayers of control C6 cells or mCD24-positive transfected C6 cells. The percentage of neurons with neurites greater than or equal to a certain length $x$ (vertical axis) was plotted as a function of neurite length $y$ (horizontal axis). The values shown are from four representative experiments.

the adult optic nerve, these results suggest that $\mathrm{mCD} 24$ may contribute to the inhibition of axon growth in the immature CNS environment.

\section{Relevance of in vitro observations to the pattern of CD24 in vivo expression}

The inhibitory effect of mCD24 on neurite outgrowth only by late embryonic neurons suggests that its role may be primarily one of preventing inappropriate collateral sprouting in the vicinity of or within the target tissue. Thus, retinal axons begin to grow toward the colliculus at around E10-11 in the mouse, with the first axons reaching their targets at about E13.5 (Silver, 1984). In the PNS, the projection of primary afferent sensory axons to their targets commences at around E11, the first contact occurring at around E16 (Fitzgerald and Fulton, 1992). Because axon innervation continues after these early arrival dates, constraint of inappropriate additional outgrowth and sprouting is a fundamental step in establishing the complex connectivity of a functional nervous system and has been proposed as a function of other molecules, such as the myelin proteins MAG (Mukhopadhyay et al., 1994) and NI-35/250 (Caroni and Schwab, 1988a,b). Unlike mCD24, however, these molecules are expressed some time after axontarget contact, and mCD24 is downregulated only after the expression of such other molecules that may then adopt a primary axon growth-restraining role.

In culture, the large majority of embryonic and neonatal RGCs and DRG neurons express mCD24 from their soma to the tips of their growth cones, thus replicating the expression observed in vivo. Interestingly, the DRG neurons of adult mice that have undergone a sciatic nerve lesion $8 \mathrm{~d}$ previously label positively with the anti-mCD24 antibody. In vitro, a subset of adult DRG neurons, which seem universally $\mathrm{mCD} 24$-negative in intact ganglia in vivo, re-express $\mathrm{mCD} 24$, and about twice as many lumbar neurons express the glycoprotein after a conditioning lesion to the sciatic nerve (data not shown). This re-expression of $\mathrm{mCD} 24$ in the injured PNS suggests further that it has an important role to play in axon growth, and the fact that cultured adult DRG neurons are also inhibited from extending neurites on mCD24expressing C6 cells suggests that they either maintain expression of the heterophilic receptor for $\mathrm{mCD} 24$ on maturation or reexpress it after injury. Perhaps this would seem paradoxical, considering that the expression of a growth inhibitor on neighboring neurites would perturb the regeneration process, but it should be noted that in our culture paradigm, neurons plated on transfected $\mathrm{C} 6$ cell monolayers are surrounded completely by uniformly high concentrations of $\mathrm{mCD} 24$, whereas this would not be the case in the microenvironment of regenerating growth cones in vivo.

These findings on re-expression in the injured adult PNS raise the possibility that $\mathrm{mCD} 24$ is regulated similarly in the injured CNS. Taken together with its transient expression in development and its potent age-dependent inhibitory effects on neurite outgrowth in culture, these findings strongly implicate mCD24 as a novel axon growth inhibitor in the mammalian nervous system.

\section{REFERENCES}

Alterman LA, Crispe IN, Kinnon C (1990) Characterization of the murine heat-stable antigen: an hematolymphoid differentiation antigen 
defined by the J11d, M1/69 and B2A2 antibodies. Eur J InmInumol 20:1597-1602.

Bartsch U, Bartsch S, Dorries U, and Schachner M (1992) Immunohistological localization of tenascin in the developing and lesioned adult mouse optic nerve. Eur J Neurosci 4:338-352.

Bedi KS, Winter J, Berry M, Cohen J (1992) Adult rat dorsal root ganglion neurons extend neurites on predegenerated but not on normal peripheral nerves in vitro. Eur J Neurosci 4:193-200.

Caladra V, Chazal G, Nielsen PJ, Rougon G, Moreau H (1996) mCD24 Expression in the developing mouse brain and in zones of secondary neurogenesis in the adult. Neuroscience, in press.

Caroni P, Schwab ME (1988a) Two membrane protein fractions from rat central myelin with inhibitory properties for neurite growth and fibroblast spreading. J Cell Biol 106:1281-1288.

Caroni P, Schwab ME (1988b) Antibody against myelin-dssuciated inhibitors of neurite growth neutralizes nonpermissive substrate properties of CNS white matter. Neuron 1:85-96.

Chang S, Katjen FG, Raper JA (1987) Extension of neurites on axons is impaired by antibodies against specific neural cell surface glycoproteins. J Cell Biol 104:355-362.

Cheng H-J, Nakamoto M, Bergemann AD, Flanagan JG (1995) Complementary gradients in expression and binding of ELF-1 and Mek4 in development of the topographic retinotectal projection map. Cell 82:371-381.

Drescher U, Kremoser C, Handwerker C, Löschinger J, Noda M, Bonhoefer $F$ (1995) In vitro guidance of retinal ganglion cell axons by RAGS, a $25 \mathrm{kDa}$ tectal protein related to ligands for Eph receptor tyrosine kinases. Cell 82:359-370.

Fitzgerald M, Fulton BP (1992) The physiological properties of developing sensory neurons. In: Sensory neurons: diversity, development and plasticity (Scott S, ed), pp 287-306. New York: Oxford UP.

Gennarini G, Durbec P, Boned A, Rougon G, Goridis C (1991) Transfected cell surface protein mediates intercellular adhesion and promotes neurite outgrowth. Neuron 6:595-606.

Ghattas IR, Sanes JR, Majors JE (1991) The encephalomyocarditis virus internal ribosome entry site allows efficient coexpression of two genes from a recombinant provirus in cultured cells and in embryos. Mol Cell Biol 11:5848-5859.

Hahne M, Wenger RH, Vestweber D, Nielsen PJ (1994) The heat-stable antigen can alter very late antigen 4-mediated adhesion. J Exp Med 179:1391-1395.

Hardy RR, Carmack CE, Shinton SA, Kemp JD, Hayakawa K (1991) Resolution and characterization of pro-B and pre-pro-B cell stages in normal mouse bone marrow. J Exp Med 173:1213-1225.

Kadmon G, Eckert M, Sammar M, Schachner M, Altevogt P (1992) Nectadrin, the heat-stable antigen, is a cell adhesion molecule. J Cell Biol 118:1245-1258.

Kadmon G, von Bohlen und Halbach F, Horstkorte R, Eckert M, Altevogt P, Schachner M (1995) Evidence for cis interaction and cooperative signalling by the heat-stable antigen nectadrin (murine CD24) and the cell adhesion molecule L1 in neurons. Eur J Neurosci 7:993-1004.

Kay R, Rosten PM, Humphries RK (1991) CD24, a signal transducer modulating $\mathrm{B}$ cell activation responses, is a very short peptide with a glycosyl phosphatidylinositol membrane anchor. J Immunol 145:1412-1416.

Kennedy TE, Serafini T, de la Torre JR, Tessier-Lavigne M (1994) Netrins are diffusible chemotropic factors for commissural axons in the embryonic spinal cord. Cell 78:425-435.

Keynes RJ, Cook GMW (1995) Repulsive and inhibitory signals. Curr Opin Neurobiol 5:75-82.

Kolodkin AL, Matthes DJ, Goodman CS (1993) The semaphorin genes encode a family of transmembrane and secreted growth cone guidance molecules. Cell 75:1389-1399.

Kuchler S, Rougon G, Marschal P, Lehmann S, Reeber A, Vincendon G, Zanetta JP (1989) Location of a transiently expressed glycoprotein in developing cerebellum delineating its possible ontogenic roles. Neuroscience 33:111-124.

Leifer D, Lipton SA, Barnstaple CJ, Masland SH (1984) Monoclonal antibody to Thy- 1 enhances regeneration of processes by rat retinal ganglion cells in culture. Science 232:303-306.
Lindsay RM (1988) Nerve growth factors (NGF, BDNF) enhance axonal regeneration but are not required for survival of adult sensory neurons. J Neurosci 8:2394-2405.

Luo Y, Raible D, Raper JA (1993) A protein that induces the collapse and paralysis of neuronal growth cones. Cell 75:217-227.

Miller RR, McDevitt CA (1991) A quantitative microwell assay for chondrocyte cell adhesion. Anal Biochem 192:380-383.

Mukhopadhyay G, Doherty P, Walsh FS, Crocker PR, Filbin MT (1994) A novel role for myelin-associated glycoprotein as an inhibitor of axonal regeneration. Neuron 13:757-767.

Nédelec J, Pierres M, Moreau H, Barbet J, Naquet P, Faivre-Sarrailh C, Rougon G (1992) Isolation and characterization of a novcl glycosyl phosphatidylinositol-anchored glycoconjugate expressed by developing neurons. Eur J Biochem 203:433-440.

Pierres M, Naquet P, Barbet J, Marcheto S, Marics I, Devaux C, Barad M, Hyman R, Rougon G (1987) Evidence that the hematopoietic cell subset marker J11D is attached to a glycosyl phosphatidylinositol membrane anchor. Eur J Immunol 17:1781-1785.

Price J, Turner D, Cepko C (1987) Lineage analysis in the vertebrate nervous system by retrovirus-mediated gene transfer. Proc Natl Acad Sci USA 84:156-160.

Rougon G, Alterman LA, Dennis K, Guo XJ, Kinnon C (1991) The murine heat-stable antigen: a differentiation antigen expressed in both the hematolymphoid and neural cell lineages. Eur J Immunol 21:1397-1402.

Sammar M, Aigner S, Hubbe M, Schirrmacher V, Schachner M, Vestweber D, Altevogt P (1994) Heat-stable antigen (CD24) as ligand for mouse P-selectin. Int Immunol 6:1027-1036.

Serafini T, Kennedy TE, Galko MJ, Mirzayan C, Jesscll TM, TessierLavigne $M$ (1994) The netrins define a family of axon outgrowthpromoting proteins homologous to C. elegans UNC-6. Cell 78:409-424.

Shewan D, Berry M, Bedi K, Cohen J (1993) Embryonic optic nerve tissue fails to support neurite outgrowth by central and peripheral neurons in vitro. Eur J Neurosci 5:809-817.

Shewan D, Berry M, Cohen J (1995) Extensive regeneration in vitro by early embryonic neurons on immature and adult CNS tissue. J Neurosci 15:2057-2062.

Shirasawa T, Akashi T, Sakamoto K, Takahashi H, Maruyama N, Hirokawa K (1993) Gene expression of CD24 core peptide molecule in developing brain and developing non-neural tissues. Dev Dyn 198:1-13.

Silver J (1984) Studics on the factors that govern directionality of axon growth in the embryonic optic nerve and at the chiasm of mice. J Comp Neurol 223:238-251.

Snow DM, Steindler DA, Silver J (1990) Molecular and cellular characterization of the glial roof plate of the spinal cord and optic tectum: a possible role for a proteoglycan in the development of an axon barrier. Dev Biol 138:359-376.

Snow DM, Watanabe M, Letourneau PC, Silver J (1991) A chondroitin sulfate proteoglycan may influence the direction of retinal ganglion cell outgrowth. Development 113:1473-1486.

Sperry RW (1943) Visuomotor coordination in the newt (Triturus viridescens) after regeneration of the optic nerve. J Comp Neurol 79:33-55.

Springer T, Galfré G, Secher D, Milstein C (1978) Monoclonal xenogenic antibodies to murine cell surface antigens: identification of novel lcukocytes differentiation antigens. Eur $\mathbf{J}$ Immunol 8:539-551.

Stefanova I, Horejsi V, Ansotegui IJ, Knapp W, Stockinger H (1991) GPI-anchored cell-surface molecules complexed to protein tyrosine kinases. Science 254:1016-1019.

Symington FW, Hakomori SI (1984) Hematopoietic subpopulations express cross-reactive, lineage-specific molecules detected by monoclonal antibody. Mol Immunol 21:507-514.

Wenger RH, Ayane M, Bose R, Köhler G, Nielsen PJ (1991) The genes for a mouse hematopoietic differentiation marker called the heat-stable antigen. Eur J Immunol 21:1039-1046.

Wenger RH, Kopf M, Nitschke L, Lamers MC, Kölher G, Nielsen PJ (1995) B-cell maturation in chimaeric mice deficient for the heat stable antigen (HSA/mouse CD24). Transgenic Res 4:173-183.

Wintergerst ES, Fuss B, Bartsch U (1993) Localization of janusin mRNA in the central nervous system of the developing and adult mouse. Eur $\mathbf{J}$ Neurosci 5:299-310. 